\title{
OBSERVASI PEMANFAATAN SUMBER DAYA IKAN UNGGULAN DAN STRATEGI PENGEMBANGANNYA DI PERAIRAN KABUPATEN BANGKA SELATAN
}

\section{OBSERVATION OF THE UTILIZATION OF SUPERIOR FISH RESOURCES AND ITS DEVELOPMENT STRATEGY IN SOUTH BANGKA REGENCY WATERS}

\author{
Mustaruddin* \& Julia Eka Astarini \\ Departemen Pemanfaatan Sumberdaya Perikanan, FPIK-IPB University, Bogor 16680, Indonesia \\ *E-mail: mus_m03@yahoo.com
}

\begin{abstract}
South Bangka Regency is surrounded by sea waters which are in the central position of three fish migration routes (Strait of Malacca, Java Sea, and Natuna waters). Therefore, it has a great opportunity to develop its fish resources. This study aims to analyze the types of superior fish resources, production trends, and formulate priority strategies for the development of superior fish resources in South Bangka Regency waters. The methods used are the scoring method, curve estimation model, and the AHP method. Squid, shrimp, grouper, red snapper, and mackerel were selected as superior fish resources. The production trend of squid, red snapper, and grouper followed the polynomial model, while shrimp and mackerel were each logarithmic and exponential. The priority strategies for the development of superior fish resources in South Bangka Regency waters were promotion of optimizing the utilization of superior fish resources $(R K=0.250)$, introduction of technology and creative activities in fishing $(R K=0.217)$, and development of fisheries business based on regional potential $(R K=0.167)$.
\end{abstract}

Keywords: fishing, strategy, superior, production

\begin{abstract}
ABSTRAK
Kabupaten Bangka Selatan dikelilingi oleh perairan laut yang berada di posisi sentral tiga jalur migrasi ikan (Selat Malaka, Laut Jawa, dan perairan Natuna). Oleh karenanya, berpeluang besar untuk mengembangkan sumber daya ikan yang dimilikinya. Penelitian ini bertujuan menganalisis jenis sumber daya ikan unggulan, trend produksinya, serta merumuskan strategi prioritas pengembangan sumber daya ikan unggulan di perairan Kabupaten Bangka Selatan. Metode yang digunakan adalah metode scoring, model curve estimation, dan metode AHP. Cumi-cumi, udang, kerapu, kakap merah, dan tenggiri terpilih sebagai sumber daya ikan unggulan. Trend produksi cumi-cumi, kakap merah, dan kerapu mengikuti model polinomial, sedangkan untuk udang dan tenggiri masing-masing bersifat logaritmik dan eksponensial. Strategi prioritas pengembangan sumber daya ikan unggulan di perairan Kabupaten Bangka Selatan adalah promosi optimalisasi pemanfaatan sumber daya ikan unggulan $(\mathrm{RK}=0,250)$, introduksi teknologi dan aktivitas kreatif dalam penangkapan ikan $(\mathrm{RK}=0,217)$, dan pengembangan usaha perikanan berbasis potensi wilayah $(\mathrm{RK}=0,167)$.
\end{abstract}

Kata kunci: penangkapan ikan, produksi, strategi, unggulan

\section{PENDAHULUAN}

Sumber daya ikan merupakan jenis sumber daya dapat pulih (renewable) namun bersifat terbatas. Artinya, sumber daya ikan dapat memulihkan kembali kondisi stoknya setiap terjadi pengurangan baik dalam bentuk pemanfaatan maupun kematian alami, selama pengurangan tersebut terjadi dalam batas yang wajar. Oleh karena sifat pulihnya dan tersebar pada perairan yang luas, maka sumber daya ikan dapat diandalkan sebagai sumber utama protein hewani sekaligus penggerak ekonomi di Kabupaten Bangka Selatan. Hal tersebut realistis, mengingat potensi perikanan laut Kabupaten Bangka 
Selatan mencapai 64.000 ton/tahun atau setara dengan Rp512 milyar/tahun, sementara tingkat pemanfaatannya belum optimal (underfishing) (DPPP Kabupaten Bangka Selatan, 2018a, Mayu et al., 2018). Di samping itu, hampir semua wilayah Kecamatan di Kabupaten Bangka Selatan (7 dari 8 kecamatan) berbatasan langsung dengan perairan laut, sehingga memberi banyak peluang bagi masyarakat di Kabupaten Bangka Selatan untuk memanfaatkan sumber daya ikan laut sebagai sumber mata pencaharian.

Menurut UU No. 45 tahun 2009 dan FAO (1995), pengelolaan dan pemanfaatan sumber daya ikan harus ditujukan untuk tercapainya manfaat yang optimal dan berkelanjutan, serta terjaminnya kelestarian sumber daya ikan. Hal ini perlu dilakukan pada semua aktivitas pemanfaatan, baik yang menggunakan kapal ukuran besar, sedang, maupun kecil, tanpa menimbulkan kerusakan pada ekosistem dan habitat ikan. Sedangkan menurut Merrifield et al. (2019) dan Karnan et al. (2012), untuk mendapatkan manfaat optimal, maka jenis sumber daya ikan yang menjadi sasaran pemanfaatan harus dipilih dari jenis-jenis ikan unggulan yang bernilai ekonomis tinggi. Hal ini penting supaya tujuan pemanfaatan dapat terpenuhi tanpa harus melakukan eksploitasi destruktif dan berlebihan yang melampaui kemampuan sumber daya ikan untuk pulih. FAO (2014) menyatakan bahwa sumber daya ikan unggulan merupakan sumber daya ikan yang dalam pemanfaatannya terpenuhi prinsip/kriteria keberlanjutan seperti keterjaminan produksi, pasar, dan dampak terkendali sesuai skala pengelolaannya.

Kabupaten Bangka Selatan berpeluang besar untuk mengoptimalkan pemanfaatan sumber daya ikan yang dimilikinya, terutama dalam konteks pengelolaan ikan unggulan. Hal ini karena wilayah Kabupaten Bangka Selatan dikelilingi oleh perairan pantai yang luas dan berada di posisi sentral tiga jalur migrasi ikan, yaitu Selat Malaka, Laut Jawa, dan perairan Natuna. Di samping itu, wilayah Kabupaten Bangka Selatan juga relatif dekat dengan pasar-pasar potensial, seperti Singapura, Hongkong, dan Jakarta. Posisi strategis ini sangat menunjang pemanfaatan sumber daya ikan yang optimal untuk menjadi sandaran penting mata pencaharian masyarakat dan penggerak ekonomi wilayah (DPPP Kabupaten Bangka Selatan, 2018a; Oktariza et al., 2016). Kedekatan wilayah Kabupaten Bangka Selatan dengan pasar potensial luar negeri juga memperkuat promosi dan diplomasi nasional bahwa Indonesia dapat mengelola dan memanfaatkan sumber daya ikan unggulan sesuai kriteria keberlanjutan yang disyaratkan oleh FAO (2014). Hal ini sangat penting untuk optimalisasi produksi ikan di wilayah Kabupaten Bangka Selatan dan sekitarnya, tanpa sedikitpun produknya mendapatkan penolakan dari pasar-pasar potensial luar negeri.

Namun demikian, produksi ikan di Kabupaten Bangka Selatan belum stabil, padahal trend produksi terutama untuk jenis unggulan merupakan informasi penting yang dibutuhkan pasar potensial. Menurut Mayu et al. (2018) dan DPPP Kabupaten Bangka Selatan (2018b), produksi ikan laut di Kabupaten Bangka Selatan pada tahun 2013 mencapai 44.975 ton, kemudian turun pada tahun 2014 (39.471 ton), naik lagi pada tahun 2016 (50.302 ton), dan turun lagi pada tahun 2018 (30.150 ton). Kondisi produksi yang fluktuatif ini juga menyulitkan untuk kepentingan pengembangan. Hal ini dinyatakan oleh DPPP Kabupaten Bangka Selatan (2018a), dari tiga lingkup kerja di subsektor perikanan (perikanan tangkap, perikanan budi daya, dan pengolahan hasil perikanan), hanya bidang perikanan tangkap yang belum memiliki project major (program prioritas) termasuk yang berfokus pada komoditas ikan unggulan. Penelitian ini diharapkan dapat membantu memecahkan masalah tersebut terutama untuk observasi pemanfaatan sumber daya ikan unggulan. Tujuan penelitian ini adalah menganalisis jenis sumber daya ikan unggulan dan trend produksinya, serta merumuskan strategi prioritas pengem- 
bangan sumber daya ikan unggulan di perairan Kabupaten Bangka Selatan.

\section{METODE PENELITIAN}

\subsection{Waktu dan Tempat Penelitian}

Penelitian ini dilakukan pada bulan Juli 2017 hingga Februari 2018. Tempat pelaksanaan penelitian di Kabupaten Bangka Selatan, dengan lokasi survei di 4 (empat) sentra perikanan tangkap, yaitu Toboali, Pulau Besar, Tukak Sadai, dan Pulau Lepar (Figure 1).

\subsection{Jenis Data dan Metode Pengumpulan Data}

Data yang digunakan dalam penelitian ini terdiri data jenis ikan hasil tangkapan nelayan, produksi ikan, dan penilaian stakeholder terkait strategi pengembangan sumber daya ikan di perairan Kabupaten Bangka Selatan. Data jumlah produksi ikan dikumpulkan melalui telaah pustaka terhadap data statistik perikanan tangkap Kabupaten Bangka Selatan. Data jenis ikan hasil tangkapan dan penilaian stakeholder terkait strategi pengembangan sumber daya ikan dikumpulkan dengan teknik wawancara dan pengamatan secara langsung.

Responden untuk data jenis ikan hasil tangkapan adalah nelayan pemilik/nakhoda dari usaha perikanan tangkap dominan (gillnet, bubu, handline, pancing cumi, dan bagan perahu). Jumlah responden sekitar 30 orang dari 412 orang populasi mereka di 4 (empat) sentra perikanan tangkap (Toboali, Pulau Besar, Tukak Sadai, dan Pulau Lepar). Responden nelayan pemilik/ nakhoda tersebut dipilih dengan metode accidental sampling ketika kunjungan di 4

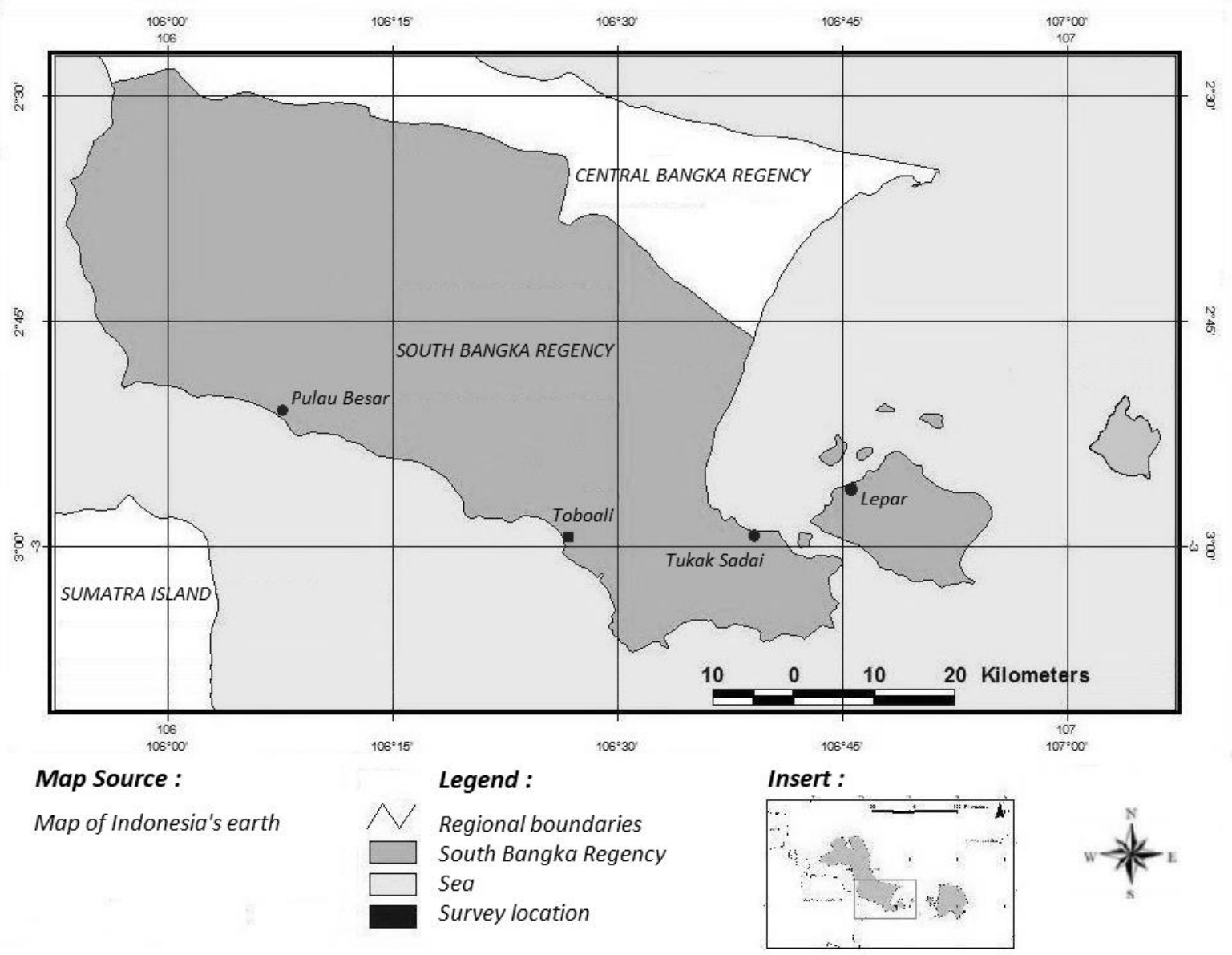

Figure 1. Research location. 
(empat) sentra perikanan tangkap Kabupaten Bangka Selatan. Sedangkan responden terkait strategi pengembangan sumber daya ikan, adalah kelompok nelayan, pelaku usaha pendukung, pengusaha perikanan, pemerintah daerah, dan masyarakat. Responden untuk setiap kelompok stakeholder dipilih secara purposive dengan kriteria mempunyai posisi/pengaruh penting dalam kelompok, aktif menjalankan usaha/beraktivitas di lokasi, dan lama (minimal 5 tahun) berinteraksi dengan kegiatan perikanan tangkap di perairan Kabupaten Bangka Selatan. Jumlah responden untuk data strategi ini masingmasing 2 (dua) orang per kelompok, dengan pertimbangan kriteria-kriteria yang diajukan sudah cukup untuk menjamin keakuratan dan konsistensi data/ informasi yang diberikan. Ariola (2006) dan Pei et al. (2019) menyatakan bahwa pengaruh dan keaktifan responden berperan besar dalam penggalian informasi yang akurat dan faktual, sedangkan pengalamannya membantu peningkatan konsistensi dan objektivitas dalam penilaian.

\subsection{Analisis Data}

Analisis data dalam penelitian ini menggunakan metode scoring, model curve estimation, dan metode AHP. Analisis scoring digunakan untuk mengobservasi jenis sumber daya ikan yang bisa dijadikan unggulan bagi Kabupaten Bangka Selatan. FAO (2014) menyatakan bahwa pemilihan kriteria keunggulan sumber daya ikan harus bersesuaian dengan prinsip keberlanjutan pengelolaan perikanan tangkap, yaitu keterjaminan produksi, pasar, dan dampak terkendali sesuai skala pengelolaannya. Mustaruddin et al. (2017) dan Sumaila et al. (2016) menambahkan bahwa kriteria unggulan dalam pemanfaatan sumber daya ikan juga perlu mencerminkan keunggulan dari sisi jumlah dan nilai produksi, serta potensi diversifikasi produknya dikaitkan dengan peluang bisnis yang ada. Mengacu hal tersebut, maka kriteria penentuan sumber daya ikan unggulan pada penelitian ini mencakup jumlah produksi, nilai produksi, kontinuitas produksi, diversifikasi produk, prospek pasar, dan dampak sosial yang ditimbulkan. Hasil penilaian setiap kriteria tersebut, kemudian distandardisasi menggunakan formula (Kuntoro \& Listiarini, 1983):

$V(X)=\frac{\left(x_{i}-x_{0}\right)}{\left(x_{1}-X_{0}\right)}$

Setelah didapatkan nilai standar dalam bentuk fungsi nilai $V(X)$, maka operasi penjumlahan dapat dilakukan untuk mendapatkan nilai skor akhir (fungsi nilai total dari semua kriteria) menggunakan formula:

$V(A)=\sum V_{i}\left(X_{i}\right)$

Pada formula 1 dan $2, V(X)=$ fungsi nilai dari kriteria $X, X i=$ nilai kriteria $X$ dari sumber daya ikan ke- $i, X O=$ nilai terendah untuk kriteria $X, X 1=$ nilai tertinggi untuk kriteria $X, V(A)=$ fungsi nilai total dari semua kriteria (nilai skor akhir) untuk sumber daya ke-i, dan $i=1,2,3 \ldots \ldots, n$ (jenis-jenis sumber daya ikan yang ditangkap nelayan). Formula 1 dan 2 dioperasikan untuk $n$ jenis sumber daya ikan yang ditangkap nelayan. Selanjutnya, $50 \%$ dari sumber daya ikan tersebut (dipilih dari yang nilai $V(A)$-nya tinggi) ditetapkan sebagai sumber daya ikan unggulan.

Model curve estimation merupakan model matematis yang diilustrasikan dalam bentuk kurva dugaan tentang perilaku atau dinamika perubahan yang terjadi pada suatu objek nyata. Dalam penelitian ini, model curve estimation digunakan untuk menduga trend produksi sumber daya ikan yang terpilih sebagai unggulan. Trend produksi suatu jenis ikan bisa berbeda satu sama lain, meskipun ditangkap pada waktu dan tempat yang sama. Oleh karena itu, maka pendugaan trend produksi ikan dalam penelitian ini menggunakan beberapa alternatif model curve estimation, yaitu:

Model regresi linear: 
$Y=a X+b$

Model polynomial:

$Y=a n X^{n}+\ldots+a 2 X^{2}+a 1 X+b$

Model logistik:

$Y=\frac{e^{(a x+b)}}{\left(1+e^{(a X+b)}\right)}$

Model logaritmik:

$Y=(a \ln (X))+b$

Model eksponensial:

$Y=b e^{a X}$

Pada model tersebut, $X=$ produksi real sumber daya ikan, sedangkan $Y=$ produksi ikan yang diilustrasikan oleh model. Kelima model curve estimation dioperasikan pada data produksi setiap jenis ikan unggulan, model yang memiliki nilai Chi Square $\left(\mathrm{R}^{2}\right)$ paling tinggi (Pei et al., 2019) ditetapkan sebagai model yang tepat untuk menggambarkan trend produksi ikan terkait.

Metode AHP digunakan untuk merumuskan strategi prioritas pengembangan sumber daya ikan unggulan. Adapun tahapan analisis yang dilakukan adalah: (a) Pendefinisian, mencakup penentuan goal (tujuan), kriteria 1 (kepentingan stakeholder), kriteria 2 (kriteria pengelolaan sumber daya ikan), dan alternatif strategi; (b) Penyusunan hierarki, yang dimulai dari level paling atas ke level paling bawah berturutturut adalah tujuan (level 1), kepentingan stakeholder (level 2), kriteria pengelolaan sumber daya ikan (level 3), dan alternatif strategi (level 4); (c) Input data dan uji banding berpasangan dengan mengacu kepada Saaty (1993); dan (d) Uji konsistensi dan uji sensitivitas. Kriteria 1 (kepentingan stakeholder) merupakan kepentingan dan harapan stakeholder terkait pengembangan sumber daya ikan unggulan di Kabupaten Bangka Selatan, dan teridentifikasi pada saat pengumpulan data. Stakeholder tersebut adalah kelompok nelayan, pelaku usaha pendukung, pengusaha perikanan, pemerintah daerah, dan masyarakat. Kriteria 2 (kriteria pengelolaan sumber daya ikan) dikembangkan dari kriteria pengelolaan perikanan yang baik menurut FAO (1995) dan FAO (2014). Sedangkan alternatif strategi disarikan dari UU No. 45 tahun 2009, BP3MD (2017), dan Sumaila et al. (2016), yaitu: (i) Pengembangan sistem open-close penangkapan ikan; (ii) Promosi optimalisasi pemanfaatan sumber daya ikan unggulan; (iii) Pengembangan usaha perikanan berbasis potensi wilayah; (iv) Pengembangan investasi industri dan pemasaran ikan hasil tangkapan; (v) Pembentukan kawasan lindung sumber daya ikan; dan (vi) Introduksi teknologi dan aktivitas kreatif dalam penangkapan ikan.

Hasil penilaian kriteria dan alternatif strategi selanjutnya diinput ke dalam software AHP (pada menu formulasi hierarki). Setelah itu, dilakukan uji konsistensi dan uji sensitivitas terhadap nilai-nilai tersebut menggunakan fasilitas inconsistency ratio test dan sensitivity test. Bila inconsistency ratio (IR) $\leq 0,1$ dan sensitivitas bersifat moderat, maka hasil analisis AHP diterima dan prioritas strategi pengembangan (muncul di bagian bawah hierarki) dapat diinterpretasikan. Selanjutnya, strategi yang mempunyai nilai prioritas atau rasio kepentingan (RK) tertinggi (50\% dari total) ditetapkan sebagai strategi prioritas untuk mendukung pengembangan sumber daya ikan di perairan Kabupaten Bangka Selatan.

\section{HASIL DAN PEMBAHASAN}

\subsection{Sumber Daya Ikan Unggulan}

Sumber daya ikan yang menjadi unggulan perlu diobservasi, supaya tindakan pengembangannya dapat dilakukan secara tepat dan optimal. Hal ini penting untuk mendukung peningkatan kesejahteraan masyarakat dan kontribusi sektor perikanan 
terhadap PDRB (BP3MD Kabupaten Bangka Selatan, 2017). Hasil identifikasi menunjukkan bahwa paling tidak, ada 10 (sepuluh) jenis sumber daya ikan yang sering ditangkap nelayan dan menjadi calon unggulan di Kabupaten Bangka Selatan, yaitu bawal hitam (Parastromateus niger), tenggiri (Scomberomorus commerson), kerapu (Plectropomus leopardus), kakap merah (Lutjanus bitaeniatus), udang (Penaeus monodon), kepiting (Portunus sexdentatus), ikan malong (Muraenesox cinerus), cumi-cumi (Sepioteuthis arctipinni), kerang darah (Anadara granosa), dan ikan pari (Dasyatis spp.). Ke-10 jenis sumber daya ikan tersebut, dominan ditangkap menggunakan gillnet, bubu, handline, pancing cumi, dan bagan perahu. Hasil wawancara kepada nelayan pemilik/nakhoda kapal-kapal terkait 10 jenis ikan calon unggulan disajikan pada Table 1.

Table 1. Results of the assessment of superior fish resources criteria.

\begin{tabular}{lcccccc}
\hline \multicolumn{1}{c}{ Fish Resources } & $\mathrm{X} 1$ & $\mathrm{X} 2$ & $\mathrm{X} 3$ & $\mathrm{X} 4$ & $\mathrm{X} 5$ & $\mathrm{X6}$ \\
\hline P. niger & 2 & 2 & 3 & 2 & 3 & 3 \\
S. commerson & 4 & 3 & 3 & 3 & 3 & 3 \\
P. leopardus & 4 & 4 & 3 & 2 & 4 & 3 \\
L. bitaeniatus & 3 & 3 & 3 & 3 & 4 & 3 \\
P. monodon & 4 & 3 & 3 & 4 & 4 & 3 \\
P. sexdentatus & 2 & 3 & 2 & 2 & 3 & 3 \\
M. cinerus & 3 & 3 & 2 & 2 & 2 & 2 \\
S. arctipinni & 4 & 4 & 3 & 4 & 4 & 3 \\
A. granosa & 1 & 3 & 3 & 1 & 2 & 3 \\
Dasyatis spp.). & 1 & 2 & 3 & 1 & 2 & 2 \\
\hline
\end{tabular}

Information: $X 1=$ production number, $X 2=$ production value, $X 3=$ production

continuity, $X 4=$ product diversification, $X 5=$ market prospect, and $X 6=$ social impact.

Pada Table 1 terdapat 6 (enam) kriteria yang digunakan untuk memilih jenis sumber daya ikan unggulan. Kriteria-kriteria tersebut membantu dalam memeriksa kehandalan sumber daya ikan dari berbagai sudut pandang, sehingga yang dikembangkan nantinya adalah yang benar-benar unggul (Sumaila et al., 2016; Karnan et al., 2012). Nilai 4 (empat) pada kriteria jumlah produksi menunjukkan jumlah produksi tinggi di Kabupaten Bangka Selatan, yaitu rata-rata bulanan di atas 100 ton, dan ini terjadi pada ikan tenggiri, kerapu, udang, dan cumi. Sedangkan jumlah produksi rendah (ratarata bulanan di bawah 25 ton), terjadi pada kerang darah dan ikan pari (nilai 1). Pada kriteria kontinuitas produksi, sebagian besar ikan bernilai 3, yang berarti dapat diproduksi pada 3 pola musim (timur, peralihan, dan barat) dalam setahun. Menurut Erwina et al. (2015) dan Karnan et al. (2012), produksi ikan yang kontinu pada 3 pola musim tersebut termasuk fantastis, mengingat sumber daya ikan perlu berkembang biak dan beberapa jenis juga bermigrasi. Nilai 4 pada kriteria prospek pasar menunjukkan bahwa jenis ikan terkait diterima baik pada semua level pasar (lokal, provinsi, nasional, dan ekspor). Khusus ikan malong, prospek pasarnya bernilai 2, karena hanya diterima pengumpul lokal yang punya jaringan langsung ke pembeli di China (ekspor). Pada kriteria dampak sosial, hampir semua jenis ikan bernilai 3, yaitu memberi manfaat kepada pelaku usaha, masyarakat umum, dan PEMDA (berupa pendapatan asli daerah).

Penilaian kriteria pada Table 1 bersifat terpisah satu sama lain, sehingga sulit menyimpulkan jenis sumber daya ikan yang benar-benar unggul. Oleh karena itu, perlu dilakukan standardisasi penilaian (Table 2) untuk mendapatkan nilai skor akhir (fungsi nilai total) pada setiap jenis sumber daya ikan.

Berdasarkan Table 2, cumi-cumi ( $S$. arctipinni), udang ( $P$. monodon), kerapu ( $P$. leopardus), kakap merah (L. bitaeniatus), dan tenggiri (S. commerson) terpilih sebagai sumber daya ikan unggulan untuk dikembangkan di Kabupaten Bangka Selatan. Cumi-cumi, udang, tenggiri, dan kerapu memenuhi kriteria jumlah produksi dengan sangat baik (nilai V1 masing-masing 1,000). Jumlah produksi cumi-cumi dan udang ter- 
Table 2. Standardization result of the assessment of superior fish resource criteria.

\begin{tabular}{lcccccccc}
\hline \multicolumn{1}{c}{ Fish Resources } & $\mathrm{V} 1$ & $\mathrm{~V} 2$ & $\mathrm{~V} 3$ & $\mathrm{~V} 4$ & $\mathrm{~V} 5$ & $\mathrm{~V} 6$ & $\mathrm{VA}$ & $\mathrm{P}$ \\
\hline P. niger & 0.333 & 0.000 & 1.000 & 0.333 & 0.500 & 1.000 & 3.167 & 6 \\
S. commerson & 1.000 & 0.500 & 1.000 & 0.667 & 0.500 & 1.000 & 4.667 & 5 \\
P. leopardus & 1.000 & 1.000 & 1.000 & 0.333 & 1.000 & 1.000 & 5.333 & 3 \\
L. bitaeniatus & 0.667 & 0.500 & 1.000 & 0.667 & 1.000 & 1.000 & 4.833 & 4 \\
P. monodon & 1.000 & 0.500 & 1.000 & 1.000 & 1.000 & 1.000 & 5.500 & 2 \\
P. sexdentatus & 0.333 & 0.500 & 0.000 & 0.333 & 0.500 & 1.000 & 2.666 & 7 \\
M. cinerus & 0.667 & 0.500 & 0.000 & 0.333 & 0.000 & 0.000 & 1.500 & 9 \\
S. arctipinni & 1.000 & 1.000 & 1.000 & 1.000 & 1.000 & 1.000 & 6.000 & 1 \\
A. granosa & 0.000 & 0.500 & 1.000 & 0.000 & 0.000 & 1.000 & 2.500 & 8 \\
Dasyatis spp.). & 0.000 & 0.000 & 1.000 & 0.000 & 0.000 & 0.000 & 1.000 & 10 \\
\hline Information:
\end{tabular}

Information: $V 1-V 6=$ the value function each of production number, production value, production continuity, product diversification, market prospects, and social impact; VA= total value function; $P=$ priority.

masuk tinggi karena banyak nelayan yang mengusahakannya, terutama nelayan skala kecil. Sementara tenggiri, pelaku usahanya tidak banyak tetapi menggunakan gillnet yang skala pengusahaannya lebih besar daripada pancing cumi dan bubu. Mayu et al. (2018) menyatakan bahwa cumi dan udang dapat ditangkap dengan mudah di Kabupaten Bangka Selatan, tidak hanya oleh nelayan skala kecil di sentra perikanan tangkap utama (Tukak Sadai, Toboali, Pulau Besar), tetapi juga oleh nelayan di Pulau Pongok dan Pulau Lepar. Jumlah produksi kerapu juga tinggi, lebih karena aktivitas penangkapan yang dipadukan dengan usaha pembesaran untuk memenuhi size ekspor kerapu.

Dari sisi nilai produksi, kerapu dan cumi-cumi mengakomodirnya dengan paling baik. Hal ini karena harga jual kedua sumber daya ikan ini lumayan tinggi baik di pasar lokal maupun ekspor. Pada ikan kerapu, harga jual di pasar lokal Kabupaten Bangka Selatan mencapai Rp275.000,00 hingga Rp325.000,00 per kg, sementara ikan lainnya, misalnya ikan pari hanya Rp55.000,00 per $\mathrm{kg}$. Hal ini dipicu oleh tingginya nilai jual ikan kerapu di pasar ekspor utama, seperti Hongkong dan Singapura (DPPP Kabupaten Bangka Selatan, 2018a; Oktariza et al., 2016). Harga jual tinggi tersebut signifikan memengaruhi pola bisnis ikan kerapu di Kabupaten Bangka Selatan dan Provinsi Bangka Belitung secara umum. Pelaku usaha sangat memperhatikan aspek pembesaran, mulai dari pakan, penanganan penyakit, hingga pengaturan kualitas air. Cukup banyak dijumpai pelaku pembesaran adalah nelayan penangkap yang ingin mendapatkan keuntungan optimal dari ikan kerapu hasil tangkapannya. Dalam konteks pengembangan sumber daya ikan unggulan, hal ini sangat bagus karena terbentuk kemandirian dan kesadaran yang tinggi di kalangan nelayan sebagai pelaku sentral perikanan tangkap. Pada cumi-cumi, nilai produksinya yang tinggi lebih dipicu oleh jumlah produksinya yang memang sudah tinggi dan bahkan tertinggi di Kabupaten Bangka Selatan (rata-rata bulanan sekitar 199,15 ton). Di samping itu, harga terbaik dalam penjualan juga mudah didapat karena produk cumi-cumi sudah menjadi ciri khas daerah kepulauan ini. Menurut Baskoro et al. (2015), cumi-cumi merupakan hasil perikanan laut yang menjadi primadona di Kabupaten Bangka Selatan, permintaannya banyak dari Pulau Jawa, Pulau Sumatra, bahkan ekspor seperti Malaysia dan Thailand. Udang kurang maksimal dalam mengakomodir kriteria ini $(\mathrm{V} 2=0,500)$, karena size-nya banyak yang tidak masuk. 
Dari sisi kontinuitas produksi dan dampak sosial, kelima sumber daya ikan unggulan dapat mengakomodirnya dengan baik (masing-masing mempunyai V3 $=1,000$ dan V6 $=1,000)$. Saat ini, produksi cumicumi di perairan Kabupaten Bangka Selatan berlangsung sepanjang tahun, dengan hasil tangkapan optimal terjadi dalam 10-11 bulan setiap tahunnya. Menurut Baskoro et al. (2015), kontinuitas produksi optimal cumicumi dapat dipertahankan dengan mengembangkan teknologi atraktor yang membantu pengkayaan stok cumi-cumi. Kontinuitas produksi tenggiri dan udang juga bagus, meskipun dengan masa optimal yang sedikit pendek daripada cumi-cumi, yaitu 9 bulan (Januari-September). Namun hal ini sangat membantu industri/usaha pengolahan (bakso, abon, keripik udang) Pulau Bangka yang produksinya meningkat sekitar bulan AprilSeptember (musim kemarau). Dari sisi prospek pasar, dapat dipenuhi dengan sangat baik oleh ikan kerapu, kakap merah, udang, dan cumi-cumi. Seperti disebutkan sebelumnya, kerapu, udang, dan cumi-cumi diterima dengan sangat baik di pasaran termasuk pasar ekspor. Sedangkan untuk kakap merah, prospek pasarnya banyak di Pulau Jawa seperti DKI Jakarta dan Jawa Barat (Kurniawan, 2018; Wiyono, 2011).

\subsection{Trend Produksi Sumber Daya Ikan Unggulan}

Guna mendukung pengembangannya kedepan, maka kondisi produksi sumber daya ikan unggulan perlu diketahui. Menurut Pei et al. (2019) dan Bogard et al. (2018), kondisi pemanfaatan/produksi terkini dapat memberi gambaran penting terkait potensi sumber daya suatu wilayah sekaligus pola pengembangannya yang tepat. Figure 2 menyajikan hasil analisis dinamika produksi sumber daya ikan unggulan di Kabupaten Bangka Selatan sepanjang tahun 2017.

Berdasarkan Figure 2, produksi cumi-cumi (S. arctipinni), udang (P. monodon), kerapu ( $P$. leopardus), kakap merah ( $L$. bitaeniatus), dan tenggiri ( $S$. commerson) di Kabupaten Bangka Selatan berlangsung sepanjang tahun 2017, meskipun ada bulanbulan yang produksinya anjlok.

Produksi anjlok untuk cumi-cumi terjadi pada bulan April dan kakap merah terjadi pada bulan September. Produksi kerapu anjlok pada bulan Juli, namun meningkat signifikan pada bulan Januari dan November. Hal-hal tersebut menunjukkan bahwa produksi sumber daya ikan unggulan di Kabupaten Bangka Selatan cukup fluktuatif. Bagi kepentingan pengembangan, hal ini kurang baik karena tidak bisa menjelas-

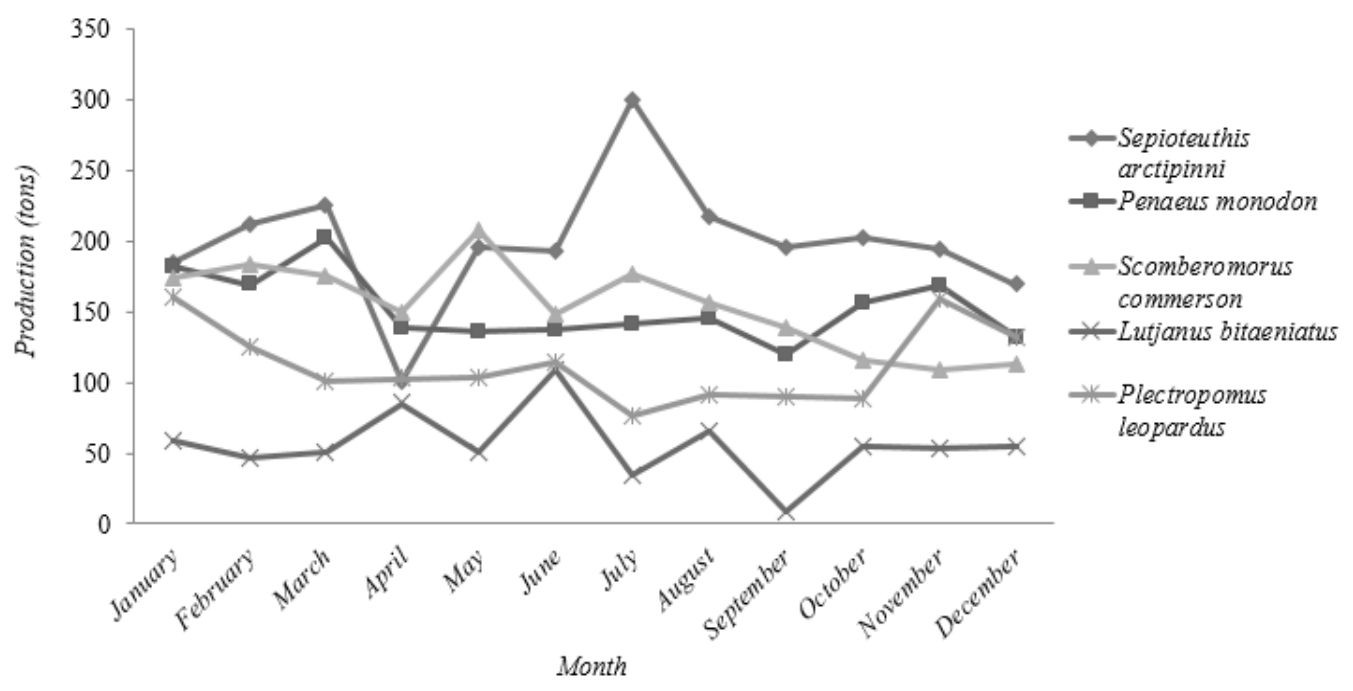

Figure 2. The dynamics of production of superior fish resources in South Bangka Regency (January-December 2017). 
kan kecenderungan/trend produksi yang terjadi. Sumaila et al. (2016) menyatakan bahwa informasi trend produksi sangat dibutuhkan untuk pengaturan penangkapan, penyiapan bahan baku industri pengolahan ikan, dan penentuan pola pengembangan perikanan kedepan. Sedangkan menurut Pei et al. (2019) dan Dewi et al. (2019), informasi trend produksi merupakan informasi dasar dalam pengembangan sistem perikanan yang terkoneksi dengan pasar-pasar potensial. Pada penelitian ini, telah dilakukan analisis tersebut untuk ke-5 sumber daya ikan unggulan terpilih dengan menggunakan model curve estimation (Figure 3).

Berdasarkan Figure 3, produksi cumi-cumi (S. arctipinni), kakap merah ( $L$ bitaeniatus), dan kerapu (P. leopardus) di.

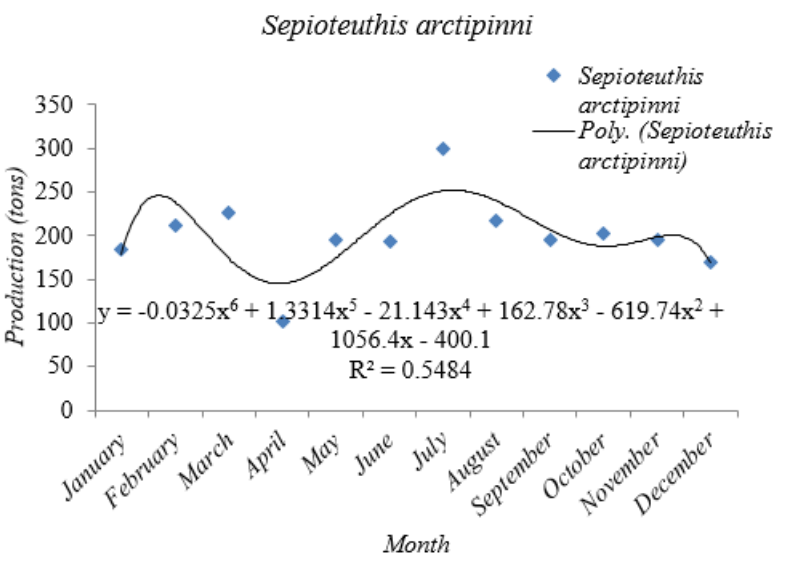

Scomberomorus commerson

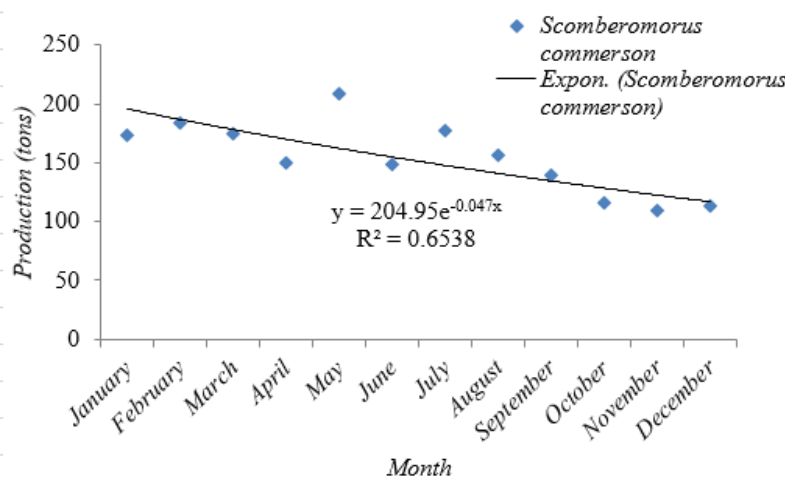

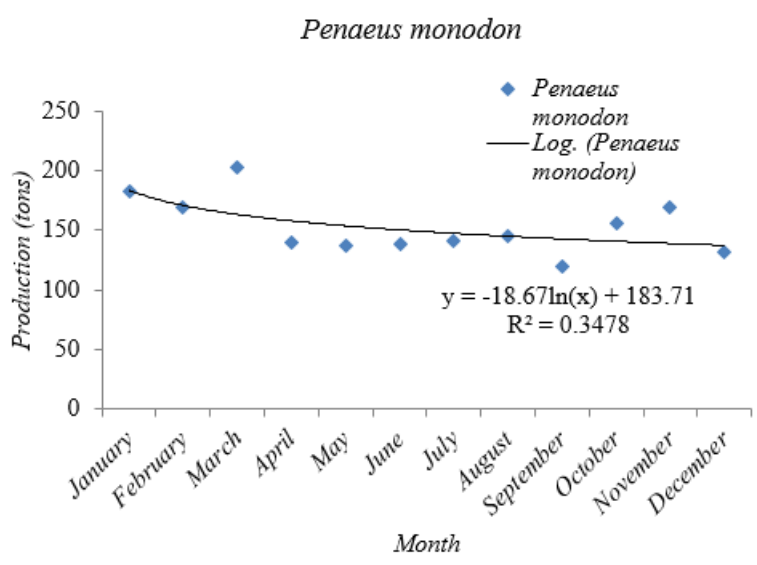

Lutjanus bitaeniatus

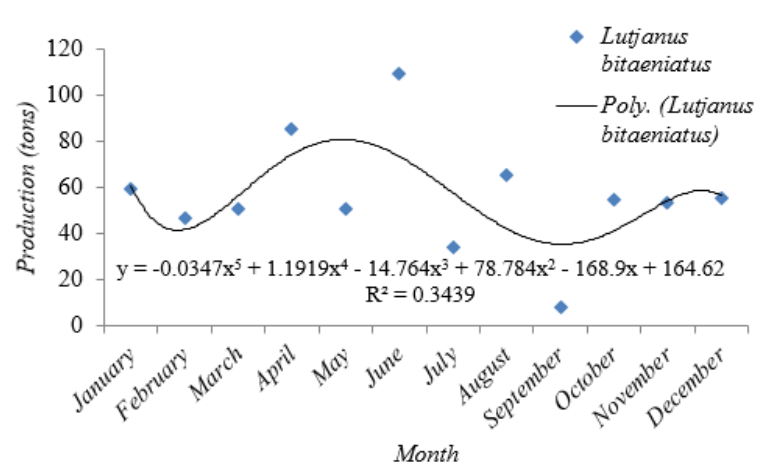

Plectropomus leopardus

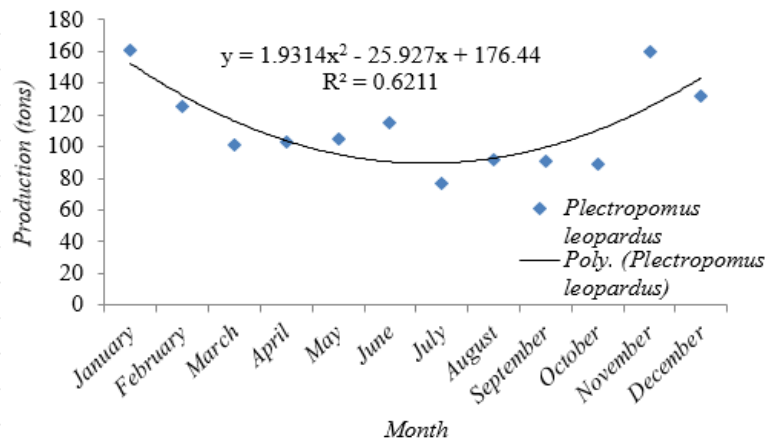

Figure 3. The production trend of superior fish resources in South Bangka Regency waters. 
perairan Kabupaten Bangka Selatan mengikuti model polinomial, yaitu naik-turun untuk setiap bulannya. Trend produksi ini termasuk dinamis dan membantu pengaturan waktu penangkapan. Menurut Gephart et al. (2017) dan Mustaruddin et al. (2011), perilaku naik turun produksi dapat merepresentasikan pola musim penangkapan ikan, dan berguna untuk pengaturan mobilisasi alat tangkap pada tahun-tahun berikutnya. Hal ini juga memudahkan pengembangan teknologi baru penangkapan ikan, kebutuhan teknologi setiap komoditas unggulan dan waktu yang cocok bagi penerapan teknologi tersebut. Bila memperhatikan jumlah puncak gelombang yang terbentuk (Figure 3), maka trend produksi cumi-cumi dan kakap merah mempunyai 2 puncak. Hal ini memberi informasi bahwa musim puncak penangkapan cumi-cumi dan kakap merah di perairan Kabupaten Bangka Selatan yang terjadi 2 kali dalam setahun. Kondisi ini tentu sangat bagus terutama untuk pengembangan kebijakan optimalisasi pemanfaatan potensi sebagaimana amanat UU No. 45 tahun 2009 dan FAO (1995) terkait tujuan pengelolaan sumber daya ikan. Peluang optimalisasi pemanfaatan 2 kali dalam setahun tersebut juga menguatkan kegiatan promosi investasi perikanan di Kabupaten Bangka Selatan.

Trend produksi udang ( $P$. monodon) bersifat logaritmik, sedangkan trend produksi tenggiri ( $S$. commerson) bersifat eksponensial, namun keduanya menunjukkan kecenderungan menurun di akhir tahun. Terkait dengan ini, maka aktivitas penangkapan udang dan tenggiri hendaknya dikurangi untuk bulan-bulan terakhir di setiap tahunnya. Menurut Mustaruddin et al. (2017) dan Erwina et al. (2015), pengurangan aktivitas penangkapan sangat membantu pemulihan stok sumber daya ikan dan hendaknya dapat diprogramkan secara berkala. Sedangkan menurut Suman et al. (2018) dan Baskoro et al. (2015), penghentian atau pengurangan aktivitas penangkapan dalam waktu cukup lama (3-6 bulan) membantu pemilihan stok secara signifikan. Hal ini dimungkinkan karena fase matang gonad telah dilampaui.

\subsection{Strategi Pengembangan Sumber Daya Ikan \\ Pengembangan sumber daya ikan} harus dilakukan dengan memperhatikan kepentingan para stakeholder utama di lokasi. Hal ini karena mereka merupakan pelaku langsung dan/atau akan banyak terkena dampak dari kegiatan pengembangan tersebut. Stakeholder utama terkait pengembangan sumber daya ikan di perairan Kabupaten Bangka Selatan adalah nelayan, pelaku usaha pendukung, pengusaha perikanan, pemerintah daerah, dan masyarakat (BP3MD Kabupaten Bangka Selatan, 2017). Hasil analisis data lapang menunjukkan bahwa kepentingan nelayan, pelaku usaha pendukung, dan pengusaha perikanan sangat terkait dengan kelangsungan usaha/investasi, ketersediaan sarana dan prasarana pendukung, dan aksesibilitas. Sedangkan kepentingan pemerintah daerah dan masyarakat, umumnya berkaitan dengan peningkatan kesejahteraan, perlindungan sumber daya dan lingkungan, serta kondisi sosial ekonomi yang lebih baik di masa datang. Pemenuhan kepentingan stakeholder tersebut relevan dengan tujuan pemanfaatan sumber daya ikan dalam UU No. 45 tahun 2009 dan perlu diupayakan pada setiap kebijakan/strategi pengembangan perikanan.

Namun demikian, pemenuhan kepentingan stakeholder harus dilakukan secara terkendali dengan mengedepankan prinsip/ kriteria pengelolaan perikanan yang bertanggung jawab. Hal ini penting untuk menjamin keberlanjutan pemanfaatan sumber daya ikan di masa yang akan datang (Su et al., 2016; De Freitas \& Tagliani, 2009). Figure 4 menyajikan hasil analisis kriteria pengelolaan sumber daya ikan di perairan Kabupaten Bangka Selatan dalam skala prioritas. Berdasarkan Figure 4, pertumbuhan ekonomi pesisir, destruksi aktivitas penangkapan ikan minimal, kesejahteraan pelaku perikanan yang meningkat, dan usaha 


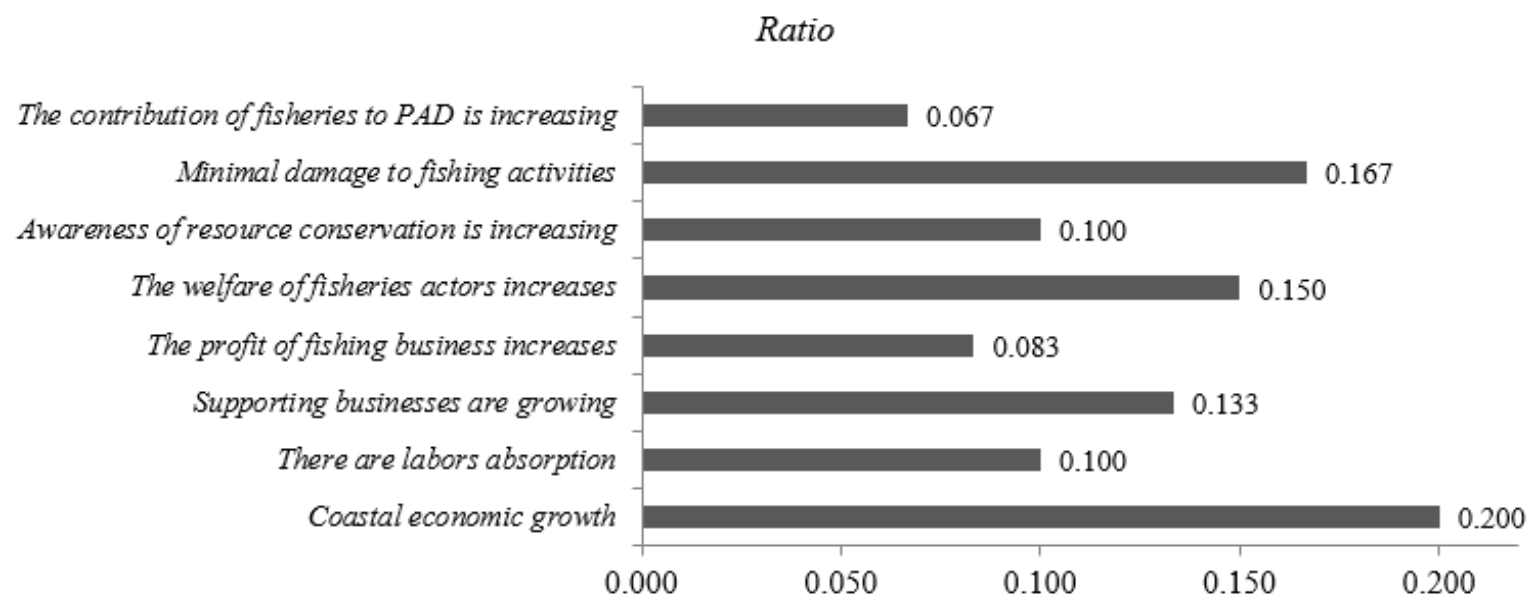

Figure 4. The criteria of superior fish resources management in South Bangka Regency waters $(I R=0.05)$.

pendukung yang berkembang merupakan kriteria pengelolaan penting $(\mathrm{RK}>0,100)$ yang perlu diperhatikan dalam pengembangan sumber daya ikan di perairan Kabupaten Bangka Selatan. Pertumbuhan ekonomi pesisir menjadi kriteria yang paling penting untuk dicapai, mengingat Kabupaten Bangka Selatan adalah wilayah kepulauan dan banyak masyarakat yang tinggal di wilayah pesisir. Menurut BP3MD Kabupaten Bangka Selatan (2017) dan De Freitas \& Tagliani (2009), aktivitas masyarakat kepulauan banyak terjadi di wilayah pesisir baik dalam pemenuhan kebutuhan hidup, berinteraksi sosial, maupun bepergian. Usaha pendukung yang berkembang juga perlu untuk memasok berbagai kebutuhan terkait pengembangan sumber daya ikan, baik pada kegiatan penangkapan, industri/usaha pengolahan, maupun distribusi hasil perikanan. Pola pemasokan dari usaha pendukung ini harus seirama dengan aktivitas penangkapan optimal dan peningkatan produksi industri/usaha pengolahan yang dibahas sebelumnya.

Pada metodologi, kriteria pengelolaan berada pada level 3, atau tepatnya di atas alternatif strategi pengembangan (level 4). Dengan demikian, maka keempat kriteria pengelolaan tersebut menjadi pertimbangan utama dalam penentuan prioritas strategi pengembangan sumber daya ikan di perairan
Kabupaten Bangka Selatan. Hasil analisis prioritas strategi tersebut dengan menggunakan software AHP disajikan pada Figure 5. Berdasarkan Figure 5, optimalisasi pemanfaatan sumber daya ikan unggulan $(\mathrm{RK}=$ 0,250), introduksi teknologi dan aktivitas kreatif dalam penangkapan ikan ( $\mathrm{RK}=$ 0,217), dan pengembangan usaha perikanan berbasis potensi wilayah $(\mathrm{RK}=0,167)$ terpilih sebagai strategi prioritas untuk pengembangan sumber daya ikan unggulan. Implementasi ketiga strategi tersebut harus memberi dampak signifikan dalam pengembangan sumber daya ikan unggulan (cumicumi, udang, kerapu, kakap merah, dan tenggiri) di perairan Kabupaten Bangka Selatan. Kurniawan (2018) dan Pascoe et al. (2014) menyatakan bahwa signifikansi dampak regulasi atau kebijakan merupakan ukuran utama keberhasilan operasionalisasi sistem tata kelola sektor kelautan dan perikanan. Sedangkan menurut Sumaila et al. (2016) dan Erwina et al. (2015), efektivitas suatu kebijakan dapat dievaluasi berdasarkan indikator dan kriteria yang dibangun sebelumnya. Pada strategi pengembangan sumber daya ikan ini, indikator dan kriteria tersebut tidak lain adalah kepentingan stakeholder dan kriteria pengelolaan yang sudah dibahas sebelumnya.

Terkait dengan ini, maka implementtasi strategi prioritas pengembangan sumber 


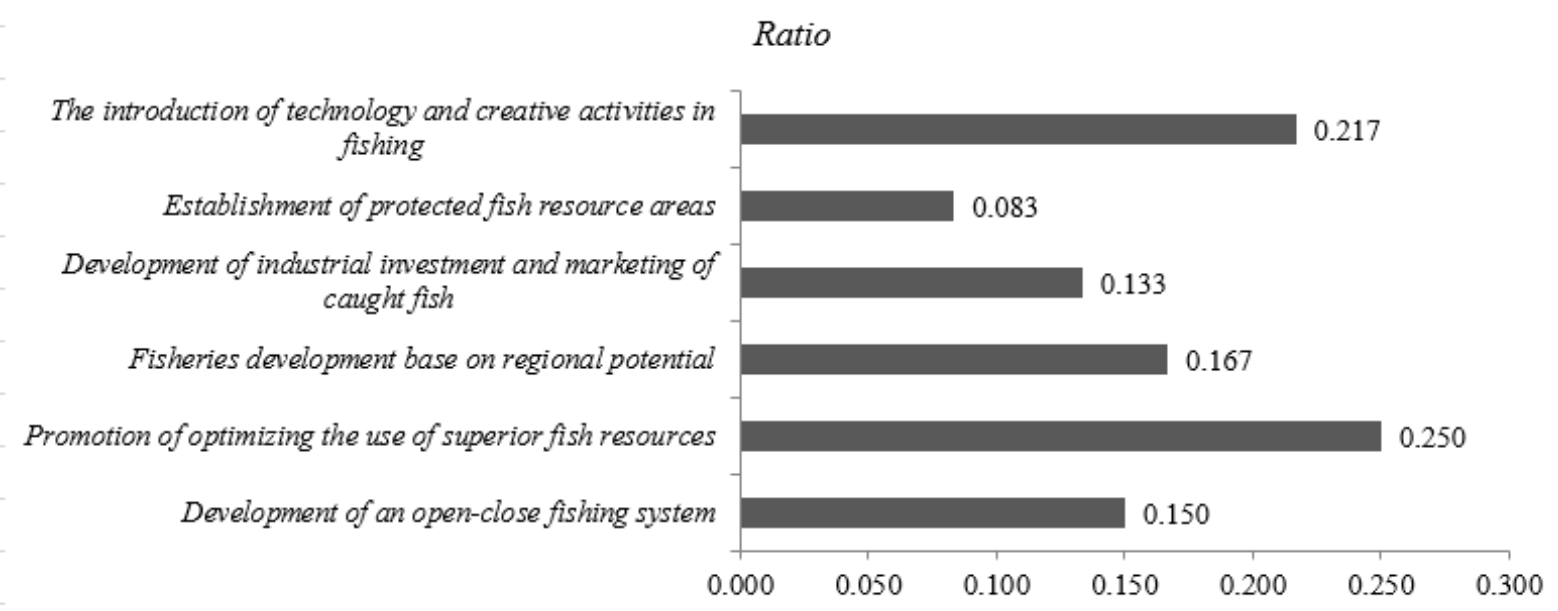

Figure 5. The development strategy of superior fish resources in South Bangka Regency waters $(I R=0.07)$.

daya ikan (tiga strategi dengan RK tertinggi pada Figure 5), perlu didesain sedemikian rupa sehingga kepentingan para stakeholder dan kriteria pengelolaan (Figure 4) dapat tercapai secara optimal. Tiga strategi lainnya yang tidak masuk prioritas dapat menjadi back-up. Berikut disajikan arahan implementtasi ketiga strategi prioritas tersebut. Pertama, strategi promosi optimalisasi pemanfaatan sumber daya ikan unggulan. Hasil analisis Table 2 menunjukkan bahwa sumber daya ikan yang unggul di perairan Kabupaten Bangka Selatan adalah cumicumi, udang, kerapu, kakap merah, dan tenggiri. Optimalisasi dalam mendukung pemanfaatan ini, maka potensi sumber daya ikan tersebut perlu terus dipromosikan, serta nelayan, usaha penyedia alat tangkap, dan pengusaha perikanan perlu diberi bimbingan keterampilan. Keterampilan tersebut dapat berkaitan dengan skill penangkapan, pengelolaan usaha, dan penanganan hasil tangkapan dari jenis ikan unggulan (Kurniawan, 2018; Mustaruddin et al., 2011). Sifat unggul (Table 1) dari kelima sumber daya ikan unggulan, harus menjadi substansi utama dalam promosi dan bimbingan.

Kedua, strategi introduksi teknologi dan aktivitas kreatif dalam penangkapan ikan. Menurut Merrifield et al. (2019) dan Baskoro et al. (2015), teknologi dan aktivitas kreatif membantu mempertahankan pro- duktivitas usaha penangkapan terutama pada bulan-bulan yang hasil tangkapannya anjlok. Berikut introduksi teknologi dan aktivitas kreatif yang direkomendasikan: (a) Penangkapan yang dipadukan dengan pemasangan rumpon ikan dan atraktor untuk cumi-cumi, terutama pada bulan April-Mei; (b) Penangkapan dengan jaring gillnet untuk tenggiri, udang, kerapu, dan kakap merah, mengikuti pola migrasi dan/atau informasi musim penangkapan ikan unggulan terkait; dan (c) Pemancingan komersial yang dipadukan wisata memancing untuk ikan tenggiri dan kakap merah. Ketiga, strategi pengembangan usaha perikanan berbasis potensi wilayah. Strategi ini dapat diarahkan pada lokasi/wilayah yang mempunyai kekhasan, potensi khusus, atau berimpit dengan aktivitas lainnya, yaitu: (a) Wisata memancing ikan tenggiri dan udang dapat diarahkan di perairan Pulau Lepar karena airnya yang jernih, cukup dangkal dan berpasir putih. Pemancingan murni komersial sebaiknya dibatasi karena trend produksi tenggiri dan udang cenderung turun (Figure 3); (b) Penangkapan sekaligus pembesaran ikan kerapu dan kakap merah diarahkan di perairan dangkal yang tenang di sekitar perairan Pulau Pongok, Toboali, Pulau Besar, dan Simpang Rimba; dan (c) Penangkapan secara umum perlu dihindari di lokasi yang padat aktivitas pertambangan dan pelayarannya, seperti per- 
airan utara Pulau Lepar dan Pulau Pongok serta perairan selatan Tukak Sadai.

\section{KESIMPULAN}

Hasil standardisasi penilaian kriteria jumlah produksi, nilai produksi, kontinuitas produksi, diversifikasi produk, prospek pasar, dan dampak sosial menunjukkan bahwa cumi-cumi, udang, kerapu, kakap merah, dan tenggiri terpilih sebagai sumber daya ikan unggulan untuk dikembangkan di Kabupaten Bangka Selatan. Trend produksi cumi-cumi, kakap merah, dan kerapu di Kabupaten Bangka Selatan mengikuti model polinomial yaitu naik-turun untuk setiap bulannya. Sedangkan untuk udang dan tenggiri, trend produksinya masing-masing bersifat logaritmik dan eksponensial. Strategi prioritas untuk mendukung pengembangan sumber daya ikan unggulan di perairan Kabupaten Bangka Selatan berturut turut adalah: promosi optimalisasi pemanfaatan sumber daya ikan unggulan $(\mathrm{RK}=$ 0,250), introduksi teknologi dan aktivitas kreatif dalam penangkapan ikan ( $\mathrm{RK}=$ 0,217), dan pengembangan usaha perikanan berbasis potensi wilayah $(\mathrm{RK}=0,167)$. Perlu dilakukan penelitian lebih lanjut tentang kapasitas stok sumber daya ikan unggulan di perairan Kabupaten Bangka Selatan.

\section{UCAPAN TERIMA KASIH}

Penulis mengucapkan terima kasih kepada para reviewer yang banyak memberikan saran dan komentar untuk perbaikan naskah ini.

\section{DAFTAR PUSTAKA}

Ariola M.M. 2006. Principles and methods of research. Rex Bookstore Inc, Sampaloc. Manila. 286 p.

Badan Perencanaan Pembangunan dan Penanaman Modal Daerah (BP3MD) Kabupaten Bangka Selatan. 2017. Profil peluang investasi Kabupaten
Bangka Selatan. BP3MD Kabupaten Bangka Selatan. Toboali. 112 p.

Baskoro, M.S., M.F. Sondita, R. Yusfiandayani, \& I.A. Syari. 2015. Efektivitas bentuk atraktor cumicumi sebagai media penempelan telur cumi-cumi (Loligo sp.). $J$. Kelautan Nasional, 10(3): 177-184. http://doi.org/10.15578/jkn.v10i3.61 91

Bogard, J.R., G.C. Marks, S. Wood, \& S.H. Thilsted. 2018. Measuring nutritional quality of agricultural production systems: Application to fish production. Global Food Security, 16(1): 54-64. https://doi.org/10.1016/j.gfs.2017.09. 004

De Freitas, M.D. \& P.R.A. Tagliani. 2009. The use of GIS for the integration of traditional and scientific knowledge in supporting artisanal fisheries management in Southern Brazil. J. of Environmental Management, 90(6): 2071-2080.

https://doi.org/10.1016/j.jenvman.20 07.08 .026

Dewi, D.A.N.N. 2019. Tingkat kepuasan peserta lelang terhadap pelayanan Tempat Pelelangan Ikan (TPI) Morodemak. J. Sumberdaya Perairan, 13(2): 122-130. https://doi.org/10.33019/akuatik.v13i 2.1123

Dinas Pertanian, Pangan, dan Perikanan (DPPP) Kabupaten Bangka Selatan. 2018a. Potensi subsektor perikanan Kabupaten Bangka Selatan tahun 2017. DPPP Kabupaten Bangka Selatan. Toboali. 74 p.

Dinas Pertanian, Pangan, dan Perikanan (DPPP) Kabupaten Bangka Selatan. 2018b. Statistik perikanan tangkap Kabupaten Bangka Selatan. DPPP Kabupaten Bangka Selatan. Toboali. $46 \mathrm{p}$.

Erwina, Y., R. Kurnia, \& Yonvitner. 2015. Status keberlanjutan sumber daya 
perikanan di Perairan Bengkulu. $J$. Sosial Ekonomi Kelautan dan Perikanan, 10(1): 21-34. http://doi.org/10.15578/jsekp.v10i1.1 245

Food and Agricultural Organization (FAO). 1995. Code of conduct for responsible fisheries (CCRF). Fisheries and Aquaculture Department of FAO. Rome. 196 p.

Food and Agricultural Organization (FAO). 2014. The state of world fisheries and aquaculture: Opportunities and challanges. Food and Agricultural Organization of the United Nations. Rome. 223 p.

Gephart, G.A., L. Deutsch, M.M. Pace, M. Troellb, \& D.A. Seekellde. 2017. Shocks to fish production: Identification, trends, and consequences. Global Environmental Change, 42(1): 24-32. https://doi.org/10.1016/j.gloenvcha.2 016.11 .003

Oktariza, W., B. Wiryawan, M.S. Baskoro, R. Kurnia, \& H.S. Wisudo. 2016. Bio-economic model of squid fisheries in the waters of Bangka Regency Bangka Belitung Islands Province. Marine Fishries, 7(1): 97107. https://doi.org/10.29244/jmf.7.1.97107

Karnan, M.S. Baskoro, B.H. Iskandar, E. Lubis, \& Mustaruddin. 2012. Potensi dan tingkat pemanfaatan sumberdaya ikan unggulan di Perairan Selat Alas Nusa Tenggara Barat. Buletin PSP, 10(4): 391-401.

https://journal.ipb.ac.id/index.php/bu lpsp/article/view/6671

Kuntoro, M. \& T. Listiarini. 1983. Analisa keputusan: Pendekatan sistem dalam manajemen usaha dan proyek. Baskara. Bandung. $52 \mathrm{p}$.

Kurniawan, K. 2018. Strategi pengembangan perikanan tangkap di Kabupaten
Bangka Selatan. J. Sumberdaya Perairan, 12(2): 93-101. https://doi.org/10.33019/akuatik.v12i 2.773

Mayu, D.H., Kurniawan, \& A. Febrianto. 2018. Analisis potensi dan tingkat pemanfaatan sumberdaya ikan di Perairan Kabupaten Bangka Selatan. J. Perikanan Tangkap, 2(1): 30-41. https://ejournal2.undip.ac.id/index.ph p/juperta/article/view/2900

Merrifield, M., M. Gleason, L. Bellquist, K. Kauer, D. Oberhoff, C. Burt, S. Reinecke, \& M. Bella. 2019. eCatch: Enabling collaborative fisheries management with technology. Ecological Informatics, 52(1): 82-93. https://doi.org/10.1016/j.ecoinf.2019. 05.010

Mustaruddin, M.S. Baksoro, O. Kandi, \& Nasruddin. 2017. Environmental and technical approach in the selection of fishing gear featured in WPP 571 Aceh. International J. of Sciences: Basic and Applied Research (IJSBAR), 31(3): 44-53. https://gssrr.org/index.php/JournalOf BasicAndApplied/article/view/6786

Mustaruddin, L.R.T. Savalas, \& P. Saptoriantoro. 2016. Penurunan hasil tangkapan ikan karang akibat kegiatan industri pariwisata di kawasan Gili Sulat dan Gili Lawang, Kabupaten Lombok Timur. J. Ilmu dan Teknologi Kelautan Tropis, 8(2): 455-468. https://doi.org/10.29244/jitkt.v8i2.15 798

Mustaruddin, Nasruddin, Sadarun, F. Kurniawan, \& M.S. Baskoro. 2011. Karakteristik perairan dalam kaitannya dengan pengembangan usaha perikanan pelagis besar di Kabupaten Aceh Jaya. Buletin PSP, 20(1): 6980.

https:/journal.ipb.ac.id/index.php/bu lpsp/article/view/4257 
Pascoe, S., A. Doshi, Q. Dell, M. Tonks, \& R. Kenyon. 2014. Economic value of recreational fishing in Moreton Bay and the potential impact of the marine park rezoning. J. of Tourism Management, 41(1): 53-63.

https://doi.org/10.1016/j.tourman.20 13.08.015

Pei, Y., M. Chen, X. Liang, \& C. Li. 2019. Model-based on fishery management systems with selective harvest policies. J. of Mathematics and Computers in Simulation, 156(1): 377-395.

https://doi.org/10.1016/j.matcom.201 8.08.009

Saaty, T.L. 1993. Pengambilan keputusan bagi para pemimpin. PT. Pustaka Binaman Pressindo. Jakarta. 270 p.

Su, M.M., G. Wall, \& M. Jin. 2016. Island livelihoods: Tourism and fishing at Long Islands, Shandong Province, China. J. of Ocean \& Coastal Management, 122(1): 20-29. https://doi.org/10.1016/j.ocecoaman. 2015.11.014

Sumaila, U.R., C. Bellmann, \& A. Tipping. 2016. Fishing for the future: An overview of challenges and opportunities. J. of Marine Policy, 69(1): 173-180.

https://doi.org/10.1016/j.marpol.201 6.01 .003

Suman, A., F. Satria, B. Nugraha, A. Priatna, K. Amri, \& M. Mahiswara. 2018. Status stok sumber daya ikan tahun 2016 di Wilayah Pengelolaan Perikanan Negara Republik Indonesia (WPP NRI) dan Alternatif Pengelolaannya. J. Kebijakan Perikanan Indonesia, 10(2): 107128.

https://doi.org/10.15578/jkpi.10.2.20 18.107-128

Undang-Undang No. 45 Tahun 2009 tentang perubahan Undang-Undang No. 31 Tahun 2004 tentang Perikanan. 53 p.

Wiyono, E.S. 2011. Alat tangkap unggulan di Kabupaten Bangka Selatan, Provinsi Bangka Belitung. Buletin PSP, 19(3): 229-238.

https://journal.ipb.ac.id/index.php/bu lpsp/article/view/4136

Received : 14 June 2020

Reviewed : 27 June 2020

Accepted : 20 Novemer 2020 
